in Fillia's 1929 painting Spirituality of Aviator. Fillia, who published a manifesto on 'The mechanical idol', presents his aviator as a fluid biomorphic shape embedded in a semi-transparent, tilted plane. Man and machine become a single permeable body with fluid boundaries. The aviator's mystical body seems to give birth to an industrial city, indicated by smoke gushing through circular openings, carrying within their stream three small buildings. Poggi explains how Fillia painted a number of other notable pictures in which landscapes and bodies merged with technology to depict a "religion of velocity".

To exemplify their message, the Futurists equated science with modernity and technology - speeding trains, giant electric power plants, bridges and abstractions from photographs. Boccioni's paintings, for example, compare and contrast the industrial radiance of science with the obscurity of the past and the oppression of natural forces, often depicted as trees, the Moon and stars. In his Study for Homage to the Mother (1907-08), he depicts two children. One is working and questioning science, with a window on to modern life. The other works by lamplight, the window showing a cloudy evening sky and a glimmering Moon. A central panel shows a tired mother with a figure on either side to symbolize the feelings of the children: one sweet and feminine, the other angry and defiant.

The final destination of this quest is illustrated in Sant'Elia's 1914 work The New City. Poggi suggests that Sant'Elia created this series of lyrical drawings of visionary hydroelectric plants to exemplify the human annexation of the energy inherent in matter. These are bold, spectacular images of geometric masses, symbolic of the dawning of a new age. The perspective in The New City is always from below, dwarfing and making the imaginary viewer insignificant.

The visions and concerns of the Futurists, Poggi tells us in this difficult, sometimes frightening but always illuminating study, emerged out of the uncertainty and confusion produced by modernity. Their artificial optimism sought to produce a philosophy for a new life, not just new art or architecture. It is not surprising that the Futurists saw an echo of excessive nationalism in their notion of modernist violence and war. Misplaced faith in science, as rational dogma, as the enemy of pessimism, as a theory of salvation, often serves as the glue that binds modernity and fascism together.

Ziauddin Sardar is the editor of Futures, the journal of policy, planning and futures studies. e-mail: futures@ziasardar.com

Futurism, an exhibition at the Tate Modern in London, opens on 12 June. For details see http://tinyurl.com/tatefuturism.

\title{
A limited view of the future
}

\section{What's Next? Dispatches On the \\ Future of Science \\ Edited by Max Brockman \\ Vintage Press: 2009. 256 pp. \$15}

Now is the time for a broad and critical look at the future of science. Just as US President Barack Obama has vowed to "restore science to its rightful place", Max Brockman has published this collection of future-oriented essays.

Brockman, a literary agent whose firm represents popular-science authors such as Jared Diamond, Richard Dawkins and Steven Pinker, has access to some of the most established thinkers. But in compiling What's Next?, Brockman chose instead to work with "the coming generation of scientists". Readers might wonder whether these young people have enough experience to provide the long view, but their biographies and publication records are impressive. For instance, climatologist Laurence C. Smith, 15 years out of a PhD, has more than 50 papers to his credit and briefs Congress on global climate change.

What's Next? is slim and readable, but lacks detailed references. Technical language is kept to a minimum, so it is accessible to a general audience. But it did not strike me as an arresting view of the future - its scope is unimaginative, covering more about what we already know than what we don't.

A pervasive theme in the book, which is heavily slanted toward psychology, is the scientific basis for ethical behaviour. Neuroscientist Christian Keysers explains that mirror neurons are activated when we perform certain activities, and when we watch others do those same activities: "The emotions of others are contagious because our brain activates our own

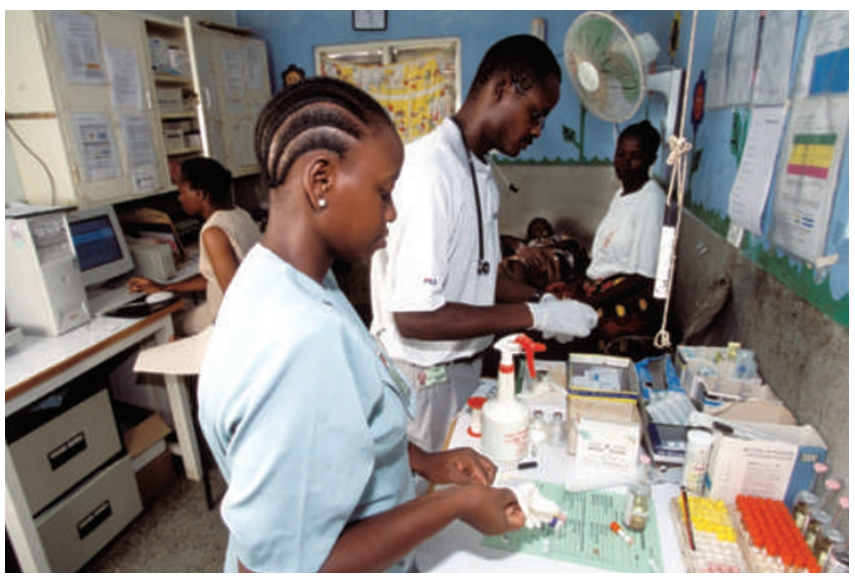

People who inherit the sickle-cell trait are protected from malaria - could other traits hold promise as genetic treatments? emotions at the sight of them." This facilitates both learning and empathy. "Our brain," he concludes, "is ethical by design."

Psychologist Joshua D. Greene sees morality as a tension between the opposing forces of intuitive emotion and cognition. "If I'm right," he says, "this tension between competing neural systems underlies not only centuriesold disagreements ... but also contemporary tussles over ... stem-cell research and the torturing of suspected terrorists." When issues are personal, the parts of the brain associated with emotional response tend to dominate, whereas in less personal situations, those regions associated with cognition are stimulated.

Philosopher Nick Bostrom tackles human enhancement. He is concerned because humans "are a marvel of evolved complexity", something with which we tamper at our own risk. So he proposes a "rule of thumb, for identifying promising human enhancements". Bostrom sees some of our limitations as resulting from selection pressures that no longer exist for most humans. Today, for instance, we can feed the higher metabolic demands of a larger brain, whereas in our recent past, we could not. We might also overcome evolutionary restrictions. Bostrom suggests that genetic 'medication' could be administered to confer an advantage, such as the protection a mutant haemoglobin gene offers against malaria in people with the sickle-cell trait. Alternatively, embryo screening could promote favourable genetic profiles. Thus, Bostrom sees the morality of human enhancement as an issue of what is achievable rather than what is acceptable. His heuristic is useful from the scientific point of view, offering us a test for whether we should even consider a particular kind of enhancement, but it probably won't

be accepted by the ethics community.

In a global society, we must all live alongside people who hold different beliefs to our own. Psychologist Matthew D. Lieberman believes that some ideas are more 'sticky' than others, and that the ideas that persist differ from one cultural group to another. $\mathrm{He}$ argues that "Big Ideas sometimes match the structure and function of the human brain such that the brain causes us 
to see the world in ways that make it virtually impossible not to believe them." Lieberman thinks that East Asian cultures stress interconnectedness among individuals, whereas Western Europeans tend to be more independent. He suggests that this tendency might be genetically influenced by a serotonin transporter gene, found twice in its 'short' variant in two-thirds of East Asians, but in only one-fifth of Western Europeans. "These cultural Big Ideas appear to have migrated until they found the populations with the right neurochemistry to make them sticky," Lieberman says.

Psychologist Lera Boroditsky asks how language influences the way we think: "People who speak different languages do indeed think differently and ... even flukes of grammar (such as the particular gender assigned to a noun in different languages) can profoundly affect how we see the world."

Modern science is highly specialized, but many scientists agree that interdisciplinary research is crucial to future work. Climatologist Gavin Schmidt asks why specialization has not led to the complete Balkanization of science, remarking that "It has been suggested that the physicist, physician, and Egyptologist Thomas Young (1773-1829) was the last person to 'know everything."' Schmidt seeks to distinguish between those fields that are separate out of necessity, and those that are mere artefacts of the way we organize our institutions. Fields become established because "the older, pioneering generation wants to employ and promote successors in its own mold; the younger generation wants to emulate its mentors", he says. But then "jargon excludes most of those outside the subfield". Schmidt warns us of the barriers that will have to be broken down, but he does not provide a good solution for doing so.

What Next? covers other ground, including global climate change, virus metagenomics, dark matter, entropy, the perception of time and the question of what makes us human. But there is surprisingly little coverage of computing or computational biology, engineering, space travel and colonization, personalized medicine, biotechnology, stem-cell biology, human cloning or artificial intelligence. The authorship is biased toward US male psychologists, and other voices might have broadened the perspective. Ideally, the book should have been twice the size, laden with references and with less repetition, and really pushing the edge. Scientists must not leave the future entirely in the hands of science-fiction writers.

Michael A. Goldman is professor and chair of

the Department of Biology at San Francisco State University, California 94132-1722, USA.

e-mail: goldman@sfsu.edu

\section{Galileo and the Pope}

\section{Two Men of Florence \\ by Richard N. Goodwin \\ Huntington Theatre, Boston, Massachusetts 6 March to 5 April 2009}

Richard Goodwin's engrossing, witty and moving - if somewhat ahistorical - play about Galileo Galilei and Pope Urban VIII recently completed a run in Boston, Massachusetts, with a fine production mounted by the Huntington Theatre Company. Significantly reworked since its original production in 2003, Two Men of Florence deserves to become a classic.

Goodwin retains a reference to the title of his earlier version, The Hinge of the World, which plays on the alternative meaning of 'hinge' as 'cardinal. Having completed the masterpiece that will destroy his standing with the Catholic Church, Galileo says to his daughter, "You and I, Maria, the saint and the philosopher, together we lean on the hinge of the world." Goodwin's depiction of their relationship, a role enhanced since the earlier production, deviates from the historical one that Dava Sobel described so compellingly in her 1999 book Galileo's Daughter.

Far from the play's portrayal of Maria as an essential collaborator in her father's work, the real Maria Celeste was placed in a convent at the age of 13 , where she served as an apothecary. Although she read her father's books and letters, her assistance was limited to supplying him with medications and moral support. Galileo drew comfort from her letters as he endured his confrontation with the Inquisition and the Pope in 1633, following the publication of his controversial work 'Dialogo'.

Goodwin's new title for the play focuses the audience's expectations more properly on the complicated relationship between Galileo the scientist and Urban the cleric. Both native Tuscans, they discover that they are intellectual compatriots. Galileo recognizes Urban as "a philosopher", an identification that Urban accepts with a slight modification: "Not a philosopher, Galileo, but at least a man of Florence, one who understands that the light of philosophy can enhance the radiance of faith." The Boston production was well served by the two actors in the starring roles: Edward Herrmann as Cardinal Maffeo Barberini, later Pope Urban VIII, and Jay O. Sanders as Galileo.

In Goodwin's rendering, the Pope encourages Galileo to write a "discussion between the followers of Copernicus and the supporters of Aristotle, a dialogue which contains

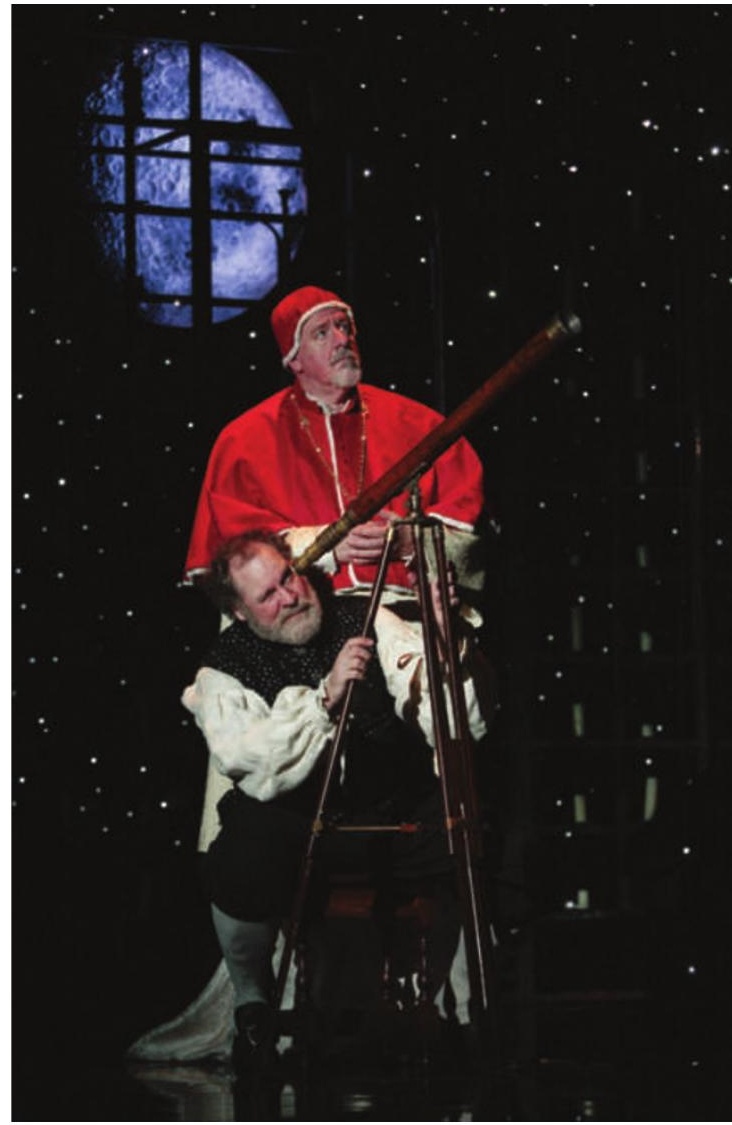

Richard Goodwin's play explores the personal interactions between Galileo and Pope Urban VIII.

arguments of all schools, in language which every educated man will comprehend". When Galileo tells Urban that his working title is On the Flux and Reflux of the Tides, the Pope advises him otherwise: "Since it is a dialogue, why not call it such - A Dialogue on the Two Great World Systems." Although renaming the book was a requirement of the Inquisition, it was dramatic licence to make it the suggestion of the Pope himself.

Both are men of towering ambition, and each ultimately feels betrayed by the other. After reading Galileo's pro-Copernican magnum opus, the Pope complains. He had, he thought, received a promise that the book would give equal treatment to each side, Copernican and Ptolemaic: "He deceived me. He betrayed his word. He makes a joke of Christianity." When Galileo learns that as a result of what he has written he will be under house arrest and his works banned, the scientist says, "This was never discussed. Never agreed."

In 1992, Pope John Paul II said, although falling short of an apology, "A tragic mutual 